\title{
Vulvar Cancer pM1 TNM Finding v7
}

National Cancer Institute

\section{Source}

National Cancer Institute. Vulvar Cancer pM1 TNM Finding v7. NCI Thesaurus. Code C89440.

Vulvar cancer with distant metastasis (including pelvic lymph node metastasis). (from AJCC 7th Ed.) 